\title{
Seroprevalence of Brucellosis from Pigs: The First Report in Central Ethiopia
}

\author{
Mulisa Megersa Kebeta ${ }^{1 *}$, Gezahegn Mamo², Tesfu Kassa ${ }^{3}$, Mebratu Assaye ${ }^{4}$, Hagos Ashenafi² and Endrias Zewdu ${ }^{5}$
}

${ }^{1}$ College of Veterinary Medicine, Jigjiga University, Jigjiga, Ethiopia

${ }^{2}$ College of Veterinary Medicine and Agriculture, Addis Ababa University, Bishoftu, Ethiopia

${ }^{3}$ Aklilu Lemma Institute of Pathobiology, Addis Ababa University, Addis Ababa, Ethiopia

${ }^{4}$ Faculty of Veterinary Medicine, University of Gonder, Gonder, Ethiopia

${ }^{5}$ Department of Veterinary Laboratory Technology, Faculty of Agriculture and Veterinary Sciences, Ambo University, Ambo, Ethiopia

\begin{abstract}
A cross-sectional study was carried out to determine seroprevalence of brucellosis from pigs in Central Ethiopia from October, 2013 to May, 2014. A total of 553 blood samples were collected and sera were tested with Rose Bengal Plate Test (RBPT). Out of 553 sera $25(4.5 \%)$ were positive for Brucella antibodies. The results showed that higher seroprevalence in young $(<12$ months) $(5.9 \%)$ and male $(8.2 \%)$ compared to adult $(\geq 12$ months $)(3.6 \%)$ and female pigs $(1.6 \%)$. The highest positive rates were obtained from pigs originated from Adama area $(13.1 \%)$ followed by pigs from Addis Ababa area (8.3\%). The study showed statistically significant difference $(P<0.05)$ in seroprevalence between origin and sexes of pigs considered. Our study demonstrated the first report of brucellosis from pigs in Central Ethiopia. Therefore further detailed investigations are needed as brucellosis has significant economic implications in pigs and public health importance.
\end{abstract}

Keywords: Brucellosis; Pig; RBPT; Central ethiopia

\section{Introduction}

Brucellosis is a serious zoonotic disease affecting man and all domestic animals including pigs. It is considered as one of the great public health problem all over the world [1]. There are five biovars of B. suis with biovars 1,2 and 3 of Brucella suis infect primarily domestic and feral pigs, as well as wild boar (Sus scrofa) [2-4]. Brucellosis in pigs is a chronic disease most often characterized by infertility and abortion in sows and by orchitis in boars [5]. The disease has drastically affected pig production through abortion, birth of weak/unthrifty piglets, infertility and orchitis in the boar and these constitute serious economic losses [6]. Extragenital lesions such as lymphadenitis, subcutaneous abscesses, arthritis, and spondylitis are also common [7]. In humans, the infection is usually confined to those who are occupationally exposed to pigs, and to laboratory workers. The capability of $B$. suis to colonize the bovine udder with subsequent shedding in milk, has the potential to be a serious human health risk [8].

The transmissions for B. suis are similar to those identified for other types of Brucella infection, being essentially the oral, nasopharyngeal, conjunctival and vaginal mucosa. There is generally a relatively long incubation period before clinical signs appear. These are not usually visible in young animals, and their occurrence will depend mainly on the age, sex and physiological state of animals at the time they are infected. As an example, animals infected during critical periods of the pregnancy (the first third to half of pregnancy) will abort approximately 30 to 45 days after infection. However, animals infected at full term do not abort. Similarly animals that are infected before the pregnancy period do not abort during their next pregnancies [9]. Infected pigs excrete Brucellas in urine, sperm, vaginal discharge, milk, and also by placenta, lochial secretion, aborted fetuses and the content of subcutaneous brucellous abscesses [10].

Swine brucellosis has been reported in domestic pigs 3\% in Greece [11] and 6.7\% in Bangladesh [12]. Other reports from Europe has also indicated, presence of brucellosis affecting wild pigs in Germany, Croatia, Spain, Switzerland and Belgium [11,13-15]. Previous studies have showed that Brucella infections are widely distributed in domesticated animals especially in the developing world [16].

The overall laboratory diagnostic regime techniques for Brucella are bacteriological, serological, phenotypic grouping and molecular based methods [17]. To date, even though, none of the serological tests has been shown to be reliable in routine diagnosis in individual pigs; indirect and competitive enzyme-linked immunosorbent assays (ELISAs), Rose Bengal test (RBT), complement fixation test (CFT) and fluorescence polarisation assay (FPA) are the prescribed tests for international trade purposes [8].

Report has indicated that no study was done to determine prevalence of brucellosis (Brucella suis) in pigs in East Africa and the occurrence and epidemiology of brucellosis in pigs was poorly understood [18]. In Ethiopia, although the population of pigs has shown increment from 19,000 in 1980 [19] to 29,000[20], in the industry is still at its infancy. In the past years adequate emphasis was not given for the sector. Unlike other livestock distribution, swine farms are predominantly found in the central part of the country particularly, in Addis Ababa and its surroundings [21]. Several studies have attempted to determine the seroprevalence of brucellosis in ruminants and humans in some regions of the Ethiopia with variable of estimates depending mainly on the analyzed host species, geographic localization, and the serological technique used [22-24] and brucellosis is among the major diseases that seriously hampers livestock industry with significant reproductive

*Corresponding author: Mulisa Megersa Kebeta, College of Veterinary Medicine, Jigjiga University, Jigjiga, Ethiopia, Tel: +251-913110517; E-mail: mulisam38@gmail.com

Received November 24, 2014; Accepted January 28, 2015; Published January 30, 2015

Citation: Kebeta MM, Mamo G, Kassa T, Assaye M, Ashenafi H, et al. (2015) Seroprevalence of Brucellosis from Pigs: The First Report in Central Ethiopia. J Veterinar Sci Technol 6: 215. doi:10.4172/2157-7579.1000215

Copyright: (c) 2015 Kebeta MM, et al. This is an open-access article distributed under the terms of the Creative Commons Attribution License, which permits unrestricted use, distribution, and reproduction in any medium, provided the original author and source are credited. 
losses in the country. Brucellosis has not been reported in domestic pigs in Ethiopia. Therefore the objective of this study was to describe the status of brucellosis in domestic pigs using Rose Bengal Plate test in Central Ethiopia.

\section{Materials and Methods}

\section{Description of study area and animals}

The study was conducted in pig farms and pigs brought at Addis Ababa slaughterhouse from the three purposively selected sites in Central Ethiopia namely Addis Ababa, East Shewa (Bishoftu and Adama) and West Shewa (Ambo area) (Figure 1). The selections of those study areas were mainly based on availability of pig farms and easy of accessibility in terms of distance from Bishoftu College of Veterinary Medicine and Agriculture. The majority of pigs considered for this study were from Bishoftu because many large and small scale commercial pig farms are concentrated around this area.

Bishoftu and Adama are found in East Shewa Zone of Oromia Regional State at a distance of 45 and $100 \mathrm{kms}$ from Addis Ababa respectively. Bishoftu is situated at a longitude of $38^{\circ} 58^{\prime} \mathrm{E}$ to $39^{\circ} 22^{\prime} \mathrm{E}$ and latitude of $08^{\circ} 22^{\prime} \mathrm{N}$ to $8^{\circ} 56^{\prime} \mathrm{N}$. The altitude of the district ranges from 1500 to over 2000 meters above sea level (masl). The area is characterized by a tepid to cool sub moist agro- ecology. The average rainfall is about $839 \mathrm{~mm}$, while the mean minimum and maximum temperatures recorded for 27 years ranged from $7.9^{\circ} \mathrm{C}$ to $28^{\circ} \mathrm{C}$ with an overall average of $18.5^{\circ} \mathrm{C}$ (IPMS, 2004). Adama is situated $1600-1700$ masl and in a latitude from $8^{\circ}-33.8 \mathrm{~N}$ to $8^{\circ}-36 \mathrm{~N}$ and a longitude from $39^{\circ} 11^{\prime} 57 \mathrm{E}$ to $39^{\circ} 21^{\prime} 15 \mathrm{E}$ in the Rift valley of warm climate. Its average annual weather conditions are $21^{\circ} \mathrm{C}$ with small amount of rainfall from
June to September. In general, the town has sunny and windy weather conditions [25].

Ambo district is found in West Shewa Zone of Oromia Regional State. The area is found at a longitude of $37^{\circ} 32^{\prime}$ to $38^{\circ} 3^{\prime} \mathrm{E}$, and latitude of $8^{\circ} 47^{\prime}$ to $9020^{\prime} \mathrm{N}$ and the altitude within the district ranges from 1400 to 3045 masl. The climatic condition of the area is $23 \%$ highland, $60 \%$ midland and $17 \%$ lowland with an annual rainfall and annual temperature ranging from $800-1000 \mathrm{~mm}$ and $15-29^{\circ} \mathrm{C}$, respectively. The mean temperature is $18.6{ }^{\circ} \mathrm{C}$. The rainfall is bi-modal with the short rainy season from February to May and long rainy season (over $58.8 \%$ of the total annual rainfall) from June to September. Agriculture, of mixed type, is the main occupation of the human population in the area. Major livestock reared include cattle, sheep, goats, poultry, and pack animals (mules, horses, and donkeys) [26].

Addis Ababa is the capital city of Ethiopia. It covers about $540 \mathrm{~km}^{2}$, of which $18.2 \mathrm{~km}^{2}$ is rural. The city is located at $9^{\circ} 1$ ' 48 “ $\mathrm{N}$ and $38^{\circ}$ $44^{\prime}-24$ " E at an average altitude 2,200 of 3300 masl. The annual rainfall is about $800-1100 \mathrm{~mm}$ and a mean annual maximum and minimum temperature is about $21^{\circ} \mathrm{C}$ and $27^{\circ} \mathrm{C}$ respectively [27].

\section{Study designs and sample size}

A cross-sectional study design was carried out in Central Ethiopia from October, 2013 to May, 2014. A total of 553 individual pigs were sampled from purposely selected study areas. For blood collection on farm basis and Addis Ababa abattoir systematic random sampling technique was used. Since there was no previous study of brucellosis in pigs in Ethiopia the sample size was calculated according to Thrusfield [28] by considering $50 \%$ expected prevalence $(P)$ and $95 \%$ confidence interval $(\mathrm{Z}=1.96)$ with a $5 \%$ desired absolute precision $(\mathrm{d})$ using the

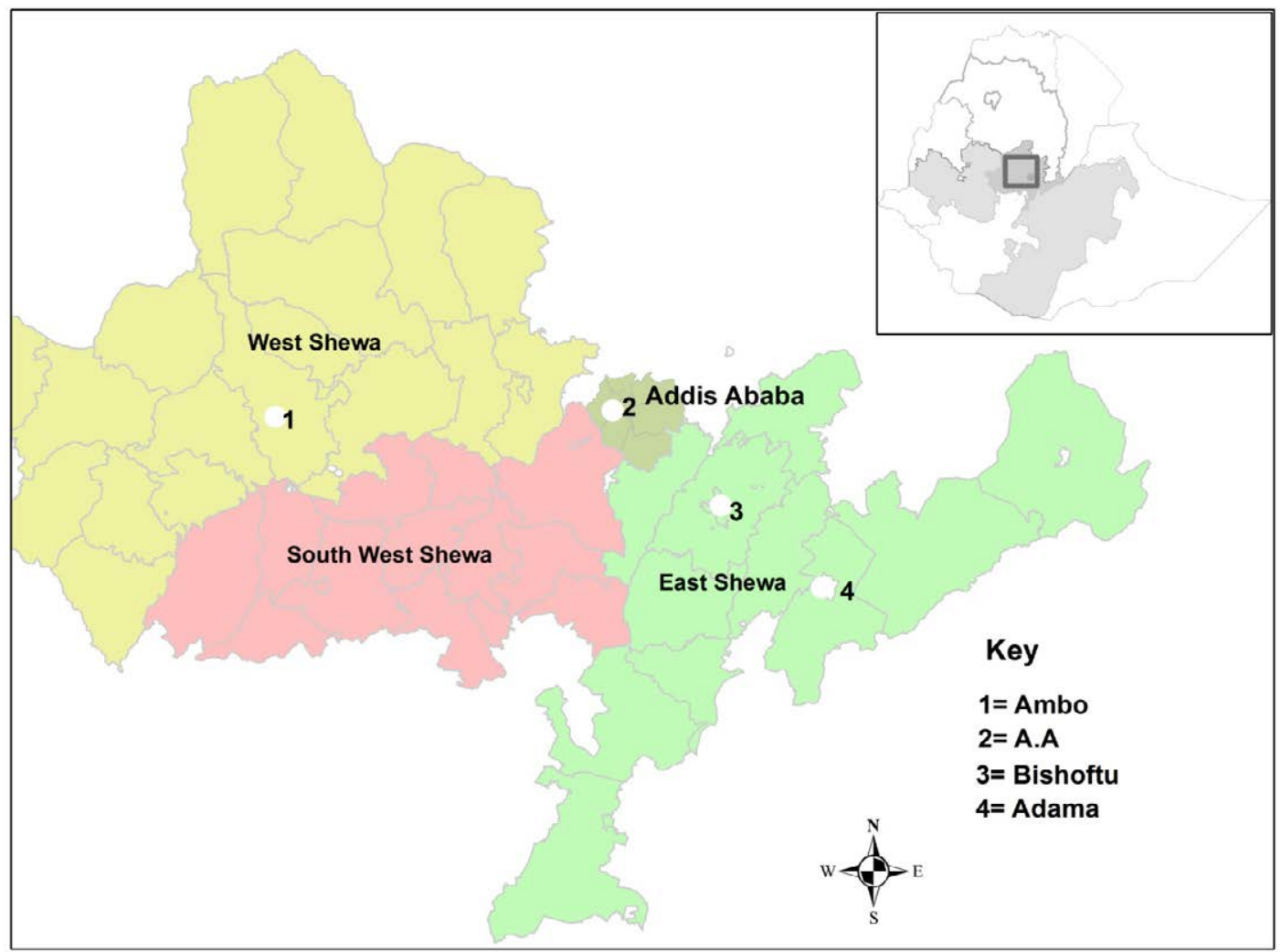

Figure 1: Study areas West Shewa (Ambo), Addis Ababa (A.A) and East Shewa (Bishoftu and Adama). 
formula $\mathrm{N}=(\mathrm{Z})^{2} P(1-P) / d^{2}$. The calculated required sample size $(\mathrm{N})$ was 384. However, total number of sampled animals was increased to 553 for better accuracy.

The abattoir was selected because slaughtered animals are obtained from all areas of the country, including from large commercial and small scale producers and the meat is sold locally by supermarket owners to consumers. The number of samples was determined by the number of animals that were slaughtered on the days of the visits and a total of 290 pigs were sampled where pigs were mainly originated from Adama, around Addis Ababa area and Bishoftu. Information recorded included sex, age and animal origin when available. Out of total pigs sampled, blood samples of 184 pigs from Bishoftu, 55 pigs from Ambo and 24 pigs from Addis Ababa Akaki kaliti sub-city were sampled from live animals in the farm.

\section{Collection of blood samples}

Blood samples were taken by venipuncture from the ear vein on farms after proper restraining of pigs and disinfected with alcohol whereas at abattoir from jugular vein at the time of slaughter with sterile plain vacutainer tubes. The samples were transported to EthioBelgium laboratory, College of Veterinary Medicine and Agriculture, with ice pack. Sera were collected following centrifugation at $300 \mathrm{rpm}$ for 10 minutes and transferred to the sterilized labeled eppendorf tube. The sera were kept at $-20^{\circ} \mathrm{C}$ until tested for antibodies against natural Brucella infection using Rose Bengal Plate Test (RBPT).

\section{Serological tests}

Brucella antigen along with positive and negative control sera were obtained from National Veterinary Institute (NVI), Ethiopia. Rose Bengal Plates Test (RBPT) was performed according to World Organisation for Animal Health (OIE) standard procedures [8]. Sera with strong agglutination were considered as positive for brucellosis. Accordingly, the formation of distinct pink granules (agglutination) was recorded as positive, while the absence of agglutination was recorded as negative.

\section{Data management and analysis}

The collected data and serological test result were entered into Microsoft Excel spreadsheet. The relationship of associated risk factor with positive serological test result was analyzed with Chi-square test using SPSS 20. A test value considered as statistically significant when $P<0.05$.

\section{Results and Discussion}

Twenty five $(4.5 \%, 95 \%$ CI: $0.028-0.063)$ out of the 553 pigs tested were positive for Brucella antibodies with RBPT. The overall seroprevalence rate found in the present study was lower as compared with the findings of $6.7 \%$ from Bangladesh [12]. Similarly it was much lower than the seroprevalence report from Nigeria (30.6\%) [29]. In contrary the results of the present study was relatively higher than the seroprevalence reported from Greece $(3 \%)$ in intensively managed swine herds [11]. The variation in this seroprevalence might have been due the disparity in geographical locations, climatic conditions and management practices in the different study areas. Other studies have also indicated that the rate of brucellosis infection varies among pig herds, from farm to farm or by country [30-32] by origin of tested pigs (wild or domesticated) [30] and by testing method used [33]. Furthermore, contact with other animals was also reported to be major risk factors that were influencing the occurrence brucellosis [34].
With regard to the age of the animal higher seroprevalence was observed in young $(<12$ months) $(5.9 \%)$ as compared to adult $(\geq 12$ months) pigs (3.6\%). This result was disagreement with the findings of Rahman et al. [12] who found higher prevalence of brucellosis in aged animal (8.1\%) than young (0.0\%). Previous study by Leite et al. [34] identified that young age of the animals as risk factor that was influencing the occurrence brucellosis.

The results of the present study showed that higher seroprevalence of brucellosis in female $8.2 \%(20 / 244)$ than male $1.6 \%$ (5/309) with significant association $(P<0.005)$. This finding was in agreement with the observation of Rahman et al. [12] who found a high prevalence of brucellosis (7\%) in female and 5.9\% in male pigs in Bangladesh. Similar observation was also recorded by other investigator in wild boar (Sus scrofa) from Republic of Croatia [5]. In contrast to this finding Ngbede et al. [29] found relatively higher prevalence of brucellosis in males than female pigs in Nigeria. The higher rate of infection in females might be due to infection within the female reproductive tract providing a potential reservoir for the organism to propagate.

The study showed highest prevalence in pigs originated from Adama area followed by Addis Ababa area and statically significant $(P<0.05)$ variation was observed among study areas (Table 1$)$. The high prevalence found in Adama and Addis Ababa area might be associated with climatic condition where Adama is located at hot lowland of Rift Valley as compared Addis Ababa situated at highland with humid climate. Previous studies have showed that Brucella suis is moderately influenced by environmental factors, with the microorganism's survival time in the environment decreasing as temperatures rise. However, the bacteria often survive desiccation and can survive freezing temperatures for over two years. Facilities and pasture can remain contaminated for long periods but direct sunlight reduces the bacteria's survival significantly [4]. Pigs originated from Addis Ababa area were mainly kept under intensive and extensive management system. Earlier studies have indicated that the main risks associated with the occurrence of brucellosis in pig farms are; introduction of infected animals [35], contact with other animals although domestic pigs are infected mainly by $B$. suis, less frequently they may become infected with $B$. abortus or B. melitensis in regions where brucellosis is endemic in cattle or small ruminants [36]. In general this study provides important information regarding the status of pig brucellosis in Central Ethiopia and the findings indicated that brucellosis is an important disease of pigs and public health concerns. Furthermore, pigs could serve as reservoirs for brucellosis and could be a potential risk of brucellosis transmission for other domestic animals.

\begin{tabular}{|c|c|c|c|}
\hline Variables & Total number & Number positive (\%) & $P$-value \\
\hline Age & & & 0.147 \\
\hline Young $\leq 12$ months & 221 & $13(5.9)$ & \\
\hline Adult $>12$ months & 332 & $12(3.6)$ & \\
\hline Sex & & & $<0.001$ \\
\hline Females & 244 & $20(8.2)$ & \\
\hline Males & 309 & $5(1.62)$ & \\
\hline Origin & & & $<0.001$ \\
\hline Ambo & 54 & 0 & \\
\hline Bishoftu & 246 & $1(0.4)$ & \\
\hline Addis Ababa area & 192 & $16(8.3)$ & \\
\hline Adama area & 61 & $8(13.1)$ & \\
\hline Total & 553 & $25(4.5)$ & \\
\hline
\end{tabular}

Table 1: Seroprevalence of brucellosis in pigs based on age, sex and origin. 
Citation: Kebeta MM, Mamo G, Kassa T, Assaye M, Ashenafi H, et al. (2015) Seroprevalence of Brucellosis from Pigs: The First Report in Central Ethiopia. J Veterinar Sci Technol 6: 215. doi:10.4172/2157-7579.1000215

\section{Conclusions}

The high seroprevalence of brucellosis observed in central Ethiopia suggested the importance of this zoonotic disease in pig production and public health. Thus, this study warrants extensive investigations to elucidate the animal and human health significance of brucellosis in the study area. Further research is required to investigate its economic importance in pig production, due to losses from abortion and infertility. Furthermore, future research is also needed to identify the types of Brucella spp and biotype affecting pigs and the underlying risk factors of brucellosis.

\section{Acknowledgments}

The authors highly acknowledge Addis Ababa University, Institute of Pathobiology, for their partial financial support. The authors also grateful to $\mathrm{Mr}$. Alemu Tola, senior laboratory technician of Ethio-Belgium laboratory, Addis Ababa University, College Veterinary Medicine and Agriculture for material support and lab permission. We would like to thank the farm owners and their workers for their support during the collection of samples.

\section{References}

1. Radostits W, Gay CC, Hinchcliff KW, Constable PD (2007) Veterinary Medicine 10thedn. Elsevier Saunders, London.

2. Corbel M (2006) Brucellosis in humans and animals. World Health Organization in collaboration with the Food and Agriculture Organization of the United Nations and the World Organization for Animal Health.

3. Cvetnić Z, Spicić S, Toncić J, Majnarić D, Benić M, et al. (2009) Brucella suis infection in domestic pigs and wild boar in Croatia. Rev Sci Tech 28: 10571067.

4. Díaz Aparicio E (2013) Epidemiology of brucellosis in domestic animals caused by Brucella melitensis, Brucella suis and Brucella abortus. Rev Sci Tech 32 : 43-5, 53-60.

5. Cventnic Z, Toncic J, Spicic J, Lojkic M, Terzic S, et al. (2004) Brucellosis in wild boar (Sus scrofa) in the Republic of Croatia. Vet. Med. Czech 49: 115-122.

6. Ogundipe GAT, Hassan JO, Olayinka OI (2001) A Comparative study of seroprevalence of Brucella antibodies in settled herds and trade cattle slaughtered in South Western Nigeria. Tropical Veterinarian 19: 52-58.

7. World Organization for Animal Health (OIE) (2011) Chapter 2.8.5 Porcine Brucellosis. In manual for diagnosis tests and vaccines for terrestrial animals.

8. World Organisation for Animal Health (Office International des Epizooties: OIE) (2009) Porcine brucellosis. In Manual of standards for diagnostic tests and vaccines, for terrestrial animals, OIE, Paris pp. 1-7.

9. Enright $F(1990)$ The pathogenesis and pathobiology of Brucella infection in domestic animals. In Animal brucellosis (K. Nielsen and J.R. Duncan, eds). CRC Press Inc., Boca Raton, Florida, pp.: 301-320.

10. MacMillan AP (1999) Brucellosis: In: Straw, BE, D'Allaire S, Mengeling WL, Taylor DJ (eds.): Diseases of Swine. 8thedn. lowa State University Press, Ames, lowa, U.S.A. Blackwell Science.

11. Burriel AR, Varoudis L, Alexopoulos C, Kritas S, Kyriakis SC (2003) Serological evidence of Brucella species and Leptospira interrogans serovars in Greek swine herds. J Swine Health Prod 11: 186-189.

12. Rahman MS, Nuruzzaman M, Ahasan MS, Sarker RR, Chakrabartty A, et al. (2012) Prevalence of brucellosis in pigs: the first report in Bangladesh. Bangl J Vet Med 10: 75-80

13. Melzer F, Lohse R, Nieper H, Liebert M, Sachse K (2007) A serological study on brucellosis in wild boars in Germany. Eur J Wild Res 53: 153-157.

14. Closa-Sebastià F, Casas-Díaz E, Cuenca R, Lavín S, Mentaberre G, et al (2010) Brucella species antibodies and isolation in wild boar in north-east Spain. Vet Rec 167: 826-828
15. Grégoire F, Mousset B, Hanrez D, Michaux C, Walravens K, et al. (2012) A serological and bacteriological survey of brucellosis in wild boar (Sus scrofa) in Belgium. BMC Vet Res 8: 80 .

16. Godfroid J (2002) Brucellosis in wildlife. Rev Sci Tech 21: 277-286.

17. Nielsen K, Gall D, Jolley M, Leishman G, Balsevicius S, et al. (1996) A homogeneous fluorescence polarization assay for detection of antibody to Brucella abortus. J Immunol Methods 195: 161-168.

18. McDermott JJ, Arimi SM (2002) Brucellosis in sub-Saharan Africa: epidemiology, control and impact. Vet Microbiol 90: 111-134

19. FAO (2004) Livestock sector brief, Ethiopia. Food and Agriculture Organization of the United Nations, Livestock Information, Sector Analysis Policy Branch.

20. FAO (2005) food and agriculture organization of the united nations.

21. Abdu S, Gashaw A (2010) Production system dynamism and parasitic interaction of swine in and around Holetta, Ethiopia. Ethiop Vet J 14: 71-81.

22. Yohannes M, Mersha T, Degefu H, Tolosa T, Woyesa M (2012) Bovine brucellosis: serological survey in Guto-Gida district, East Wollega Zone, Ethiopia. Global Veterinaria, 8: 139-143.

23. Zewold SW, Haileselassie M (2012) Seroprevalence of Brucella infection in camel and its public health significance in selected districts of Afar region, Ethiopia. J Environ Occup Sci 1 (2): 91-98.

24. Dabassa G, Tefera M, Addis M (2013) Small ruminant brucellosis: Serological survey in Yabello district, Ethiopia. Asian Journal of Animal Science 7: 14-21.

25. Taye B (2011) A Study of the Civil Service Reform in Adama City Administration: Regional State of Oromia-Ethiopia. MSc thesis, Addis Ababa University, College of Management, Information and Economic Science, Addis Ababa, Ethiopia, pp. 19-20.

26. AARDO (Ambo District Agricultural and Rural Development Office) (2010) Annual report. pp. 12-16

27. Fikire Z, Tolosa T, Nigussie Z, Macias C, Kebede N (2012) Prevalence and characterization of hydatidosis in animals slaughtered at Addis Ababa abattoir Ethiopia. J Parasitol Vector Biol 4: 1-6.

28. Thrusfield M (2005) Veterinary Epidemiology, 3rd edition, Blackwell Publishing Company, Black Well Ltd, UK.

29. Ngbede EO, Momoh AH, Bala RS, Madaki BD, Maurice NA (2013) An Abattoirbased study on serodiagnosis of swine brucellosis in Makurdi, Benue State North Central Nigeria. Journal of Advanced Veterinary Research 3: 57-59.

30. Godfroid J, Käsbohrer A (2002) Brucellosis in the European Union and Norway at the turn of the twenty-first century. Vet Microbiol 90: 135-145.

31. Adesiyun AA, Cazabon EP (1996) Seroprevalences of brucellosis, Q-fever and toxoplasmosis in slaughter livestock in Trinidad. Rev Elev Med Vet Pays Trop 49: 28-30.

32. Lord VR, Cherwonogrodzky JW, Marcano MJ, Melendez G (1997) Serologica and bacteriological study of swine brucellosis. J Clin Microbiol 35: 295-297.

33. Paulo PS, Vigliocco AM, Ramondino RF, Marticorena D, Bissi E, et al. (2000) Evaluation of primary binding assays for presumptive serodiagnosis of swine brucellosis in Argentina. Clin Diagn Lab Immunol 7: 828-831.

34. Leite AI, Coelho WAC, Silva GCP, Santos RF, Mathias LA, et al. (2014) Prevalence and risk factors for brucellosis in Mossoró-RN. Pesquisa Veterinária Brasileira 34 (6): 537-541.

35. Lord VR, Cherwonogrodzky JW, Schurig GG, Lord RD, Marcano MJ, et al. (1998) Venezuelan field trials of vaccines against brucellosis in swine. Am J Vet Res 59: 546-551.

36. European Food Safety Authority (EFSA) (2009) Porcine brucellosis (Brucella suis). EFSA J, 1144: 1-112. 